\title{
A Corpus-Assisted Critical Discourse Analysis of the Syrian Refugee Crisis in Jordanian Newspapers
}

\author{
Amal Riyadh Kitishat ${ }^{1}$, Murad Al Kayed ${ }^{1}$ \& Mohammad Al-Ajalein ${ }^{2}$ \\ ${ }^{1}$ Al-Balqa Applied University, Department of English Language, Ajloun University College, Jordan \\ ${ }^{2}$ University of Jordan, Amman, Jordan \\ Correspondence: Murad Al Kayed, Department of English Language, Al-Balqa Applied University, Jordan. \\ E-mail: murad.alkayed@bau.edu.jo
}

\author{
Received: February 11, $2020 \quad$ Accepted: August 31, $2020 \quad$ Online Published: September 15, 2020 \\ doi:10.5539/ijel.v10n6p195 URL: https://doi.org/10.5539/ijel.v10n6p195
}

\begin{abstract}
The present study employs corpus linguistics and critical discourse analysis to investigate the attitudes of Jordanian news towards the Syrian refugee crisis. The corpus of the research, which consists of 10140 articles (Word types: 103170 and Word tokens: 1956589), were taken from the Petra news agency between 2016 and 2018. Antconc Tools Version 3.4.4w was used to analyze the data. The study used corpus statistical tools of collocates and concordance. Collocates tool used to create a list of 200 collocates associated with the words: /lad3i?/ 'refugee', /lad3i2i:n/ 'refugees', /su:ri:/ 'Syrian', and /su:ryi:n/ 'Syrians'. These collocates were organized into two thematic categories: 'services and resources' and 'Jordanians and Syrians'. The study used a concordance tool to unveil the attitudes of newspapers towards the Syrian refugee crisis. The findings of the study showed that Jordanians see Syrians as "brothers" and "guests". However, Jordanian newspapers overstated the negative effect of Syrian refugees on the Jordanian economy, education, healthcare, etc. Jordanians were frustrated because Syrians compete with them on their resources and governmental services.
\end{abstract}

Keywords: corpus linguistics, critical discourse analysis, Syrian refugees, Antconc, newspapers

\section{Introduction}

\subsection{Background}

When the conflict started in Syria in 2011, Jordan has suffered from the negative impact of a massive influx of Syrian refugees. According to UNHCR, Jordan now hosts more than 1.6 million Syrians, of whom around 700,000 registered with the United Nations High Commission for Refugees. More than eighty percent of these Syrians live in Jordanian cities and villages, especially in the northern district, as opposed to refugee camps. UNHCR reveals that $29 \%$ of registered Syrian refugees live in the capital Amman, $25 \%$ in Mafraq (a city in north Jordan), and $21 \%$ in Ibid (a city in North Jordan). Nowadays, Syrian refugees constitute more than 10 percent of Jordan's population, which has influenced the social, political, and economic situation in Jordan. It is not a secret that Syrian refugees compete with Jordanians for their employment opportunities, healthcare, shelter, education, and scarce resources.

\subsection{A Corpus-Assisted Critical Discourse Analysis Approach}

Corpus linguistics (CL) studies language based on samples of naturally occurring language (Hunston, 2002). It is worth noting that corpus-based studies became the new trend/method in contemporary linguistics. Corpus linguistics is used a lot by researchers to investigate different aspects of language, such as syntax, semantics, language teaching and learning, translation, discourse analysis, etc.

One of the exciting fields that may be studied by corpus linguistics is critical discourse analysis (CDA). CDA has been examined mainly by three frameworks: Fairclough's (1995) social framework, Wodak's (2001) historical framework, and Van Dijk's (1998, 1997, 1996, 2001) cognitive framework. For Wodak (2001), CDA is interested in the ideologies and agendas implemented within discourses. For him, discourse is structured with historical factors and accumulative knowledge. For Van Dijk (2001), CDA is "a type of discourse analytical research that primarily studies the way social power abuse, dominance, and inequality are enacted, reproduced, and resisted by text and talk in the social and political context" (p. 352). For Fairclough's (2001), CDA studies texts as forms of social practices. Thus, discourse is not merely a set of sentences; instead, it reflects ideological implications 
and dominations.

The integration of CDA and CA resulted in the rise of corpus-assisted critical discourse studies (CACDAS) (Partington, 2004, 2006). According to Baker (2006), CACDA has gained growing attention from scholars. They were concerned with research that addresses immigrants, social inequalities marginalization of some minorities, and political conflicts.

The current study uses the CACDA to explore the attitudes of Jordanian newspapers towards Syrian refugees. It aims at answering the following questions:

- What do concordance analysis of the words "lad3i? 'refugee', lad3i?in 'refugees', suri: 'Syrian', and suryi:n 'Syrians' in the corpus reveal?

- What do the words "lad3i? 'refugee', lad3iin 'refugees', suri: 'Syrian', and suryi:n 'Syrians' collocate with?

- What is the attitude of Jordanians towards the Syrian refugee crisis?

\section{Literature Review}

Kandil (2009) combined Critical Discourse Analysis and corpus linguistics to investigate how media discourse represents the conflict between Israel and Palestine. The study focuses on the use of the lexical item 'terrorism' in three corpora of news reports collected from BBC, Al-Jazeera, and CNN news networks. The analysis of the data showed each network adopted different attitudes towards the Israeli-Palestinian conflict. CNN supports the Western/Israeli position and Al-Jazeera refuses that position. The BBC was less engaged than the other networks.

Salama (2011) used the corpus method and critical discourse analysis to investigate how Wahhabi-Saudi Islam been ideologically recontextualized across post-9/11 opposing discourses via collocation. The study found out that that CDA corpus methods opened new horizons of the critical study of collocations at methodological and theoretical levels.

Su and Xiao (2015) used critical discourse analysis and corpus linguistics and to explore the representation of the 'Chinese dream' among both Chinese citizens and officials based on a corpus collected from the Chinese press. The data revealed that the Chinese Dream had been successfully promoted as a slogan.

Aluthman (2018) used Corpus-assisted Critical Discourse Analysis to explore the depiction of immigration in the Brexit corpus. The corpus of the study consisted of 108,452,923 words collected from news, tweets, and blogs related to the Brexit context. The study used corpus-assisted statistical tools, such as collocation, keyword, and concordance, to analyze the data. The frequency findings revealed that immigration is one of the critical issues in the corpus. Concordance analysis of 'immigration' and 'immigrants' showed both negative and positive attitudes toward immigrants in the EU debate.

Tagnin and Teixeira (2012) used a corpus-based methodology to compile a bilingual, mono-directional English-Portuguese glossary of cooking terms. They gathered two sub-corpora: one in English and one in Brazilian Portuguese, consisting of cooking recipes collected from the Internet. After collecting the data, the researchers used WordSmith software to generate frequency and keyword lists.

Ensslin and Johnson (2006) investigated how newspapers represent themes relating to language and linguistics by using a corpus-based methodology. The corpus consisted of all articles from two British newspapers, The Guardian and The Times. The study employed the software program WordSmith Tools to identify those keywords that collocate with the words "language", "languages", "linguistic" and "linguistics". The findings of the study showed exciting ways in which language-related issues are represented in Newspapers.

Baker et al. (2013) employed a corpus-based methodology to investigate the representation of Muslims in British newspapers. The corpus used in the study is a 143 million words collected from British newspaper articles (1998-2009). The researchers used the Sketch Engine tool to analyze the noun collocates of the word "Muslim". The collocates were classified into different groups: conflict, characterizing/differentiating attributes, religion, culture, ethnic/national identity, and group/organizations. The findings of the study revealed that the 'conflict' category was lexically rich compared with other categories. The study also found out that the most frequent collocates with the word "Muslim" were "the Muslim world" and "the Muslim community". The analysis of these two pairs showed that Muslims were viewed as easily offended, isolated, and in war with non-Muslims.

Kim (2014) used a quantitative, corpus-based approach to explore the discursive practices of North Korea in US news. The corpus consisted of all texts taken from The New York Times, Newsweek, and CNN published between 1998 and 2010. The corpus composed of 69,000,175 tokens and 173,444 types: NYT (10,116 articles; 7,363,431 tokens); CNN (9054 articles; 59,929,368 tokens); and Newsweek (906 articles; 1,707,376 tokens). 
The results of the study suggested that US news divided the world into allies or enemies. The analysis also showed that US news viewed North Korea as a 'rogue' country and as a threat to world peace.

Concerning the Syrian refugee crisis, the researcher did not find many corpus-based studies that explore the attitudes towards Syrian refugees. For example, Ulum (2016) used Critical Discourse Analysis to explore the ideologies constructed in English, German, and Turkish news headlines. The study found that the western media (English and German) represented the arrival of the Syrian refugees to Europe as a threat or a risk; the Turkish media viewed the issue from a humanitarian perspective.

To the best knowledge of the author, no study tackled the attitudes towards Syrian refugees in Jordan by using Corpus-assisted Critical Discourse Analysis (CACDA). Thus, this study attempts to bridge this gap by examining the attitudes of the Jordanian press towards the Syrian refugees using CACDA.

\section{Methods}

\subsection{Data Collection}

The corpus of the current study consists of 10140 articles (Word types: 103170 and Word tokens: 1956589) taken from the Petra news agency between 2016 and 2018.

\subsection{Data Analysis}

The study adopts the methodological synergy approach coined by Baker (2006). It makes use of discourse analysis methods and corpus-assisted statistical tools, including keyword, concordance analysis and collocation. Antconc Tools Version 3.4.4 was used to analyze the data. This software provides several functions by which the behavior of words can be studied, such as Wordlist, concordance, collocates, keywords and N-gram/cluster. This study uses collocates and Concordance function.

The researcher used the collocates tool to create a list of collocates associated with the words: lad3i? 'refugee', lad3i?in 'refugees', /suri:/ 'Syrian', and /su:ryi:n/ 'Syrians'. However, before searching for these words and generating a list, it is essential to refine our search. The function words, including prepositions, articles, possessives, and conjunctions were removed from the list by using a stop list. It's crucial to remove these words from the list since they are ranked high on the list, and they are irrelevant to our study.

\section{Results and Discussion}

\subsection{Results of Collocates Tool}

The researcher used the collocates tool to create a list of collocations associated with the words /lad3i?/ 'refugee', lad3iPin 'refugees', /su:ri:/ 'Syrian', and /su:ryi:n/ 'Syrians'. The researcher then took the first 200 collates and organize them into two thematic categories, as is evident in Table 1. It is worth noting that the researcher classified 200 collocates into many categories. Still, the study is concerned with two groups: /xadamat wa mawarid/ 'services and resources' and /alPurdini:n wa alsuryi:n/ 'Jordanians and Syrians':

Table 1. Thematic categories

\begin{tabular}{|c|c|}
\hline Thematic categories & collocates \\
\hline \multirow[t]{6}{*}{ Jordanians and Syrians } & استضاف istadaf 'hosted' \\
\hline & " استقبل istaqbal 'welcomed/hosted' \\
\hline & الأثقاء al?fiqa? 'brothers' \\
\hline & Pixwanuna 'our brothers' \\
\hline & PlPxwah 'brothers' \\
\hline & Pfiqa?na 'brothers' \\
\hline \multirow[t]{6}{*}{ services and resources } & “"صحة" sihah 'health' \\
\hline & "تنعليم" taSlim 'education' \\
\hline & 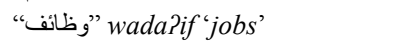 \\
\hline & “|قتصـاد"'Piqtisad 'economy” \\
\hline & " "سكن" sakan 'housing' \\
\hline & "مياه" miyah 'water' \\
\hline
\end{tabular}

\subsection{Results of Concordance Tool}

After creating thematic categories, the researcher used concordance tool to investigate recurrent patterns and the use of these patterns in context. The thematic categories were discussed below. 


\subsubsection{Jordanians and Syrians}

The first category is concerned with the type of relationship between Jordanians and Syrians. Using collocate tool reveal that Jordanians represent Syrians as الأشقاء Pixwanuna 'our brothers' (Freq: 53, Stat: 2.87043), الاخوة RlPxwah 'brothers' (Freq: 30, stat: 4.34912) and الثقائنا ?fiqa?na 'brothers' (Freq: 21, Stat: 3.069341). Consider the following concordance line:

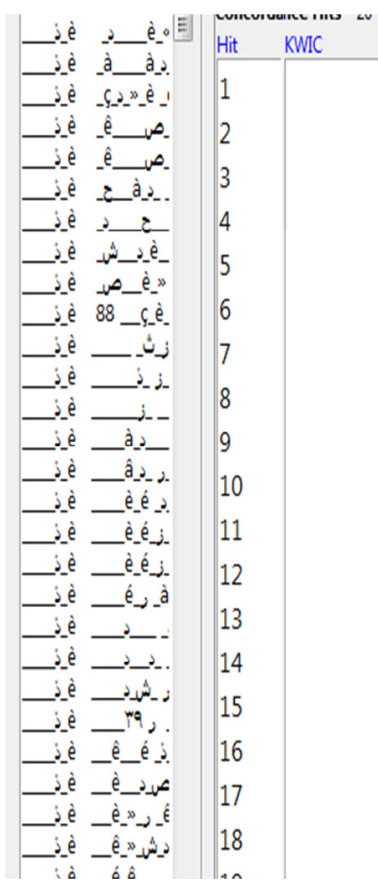

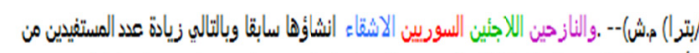

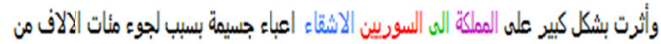

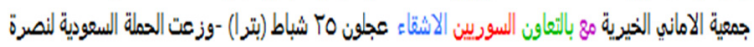

$$
\begin{aligned}
& \text { من البرامج والمشاريع العيد تنفذ السورين الاشقاء وقال السمحان ان الحملة الوطنية للسعودية لنصرة. }
\end{aligned}
$$

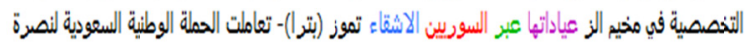

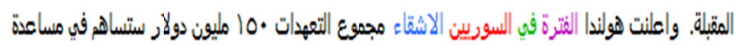

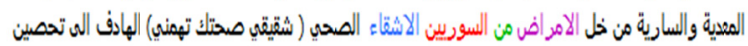

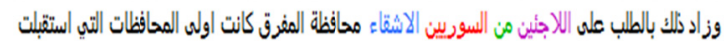

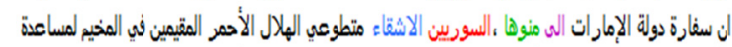

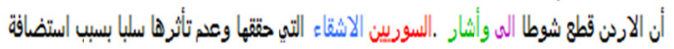

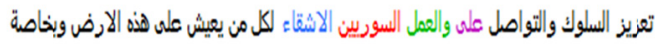

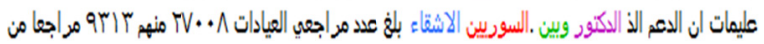

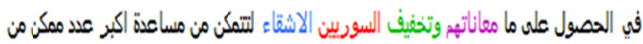

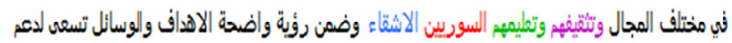

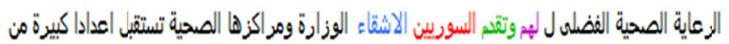

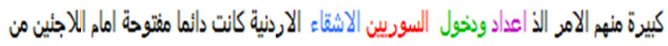

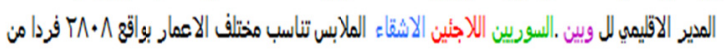

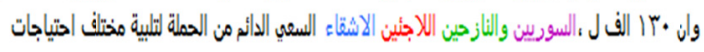

Figure 1. Collocates of Jordanians and Syrians

As it is clear from the concordance line above, the word "الشقاء" al2fiqa? 'brothers' collocates with " لسوزيبين" alsuryun 'Syrians' which suggests that despite the negative impact of Syrian refugee crisis on Jordan; Jordanians viewed Syrians as their brothers. Jordanian feel that they are obliged to stand with their "brothers" in their crisis. It is essential to understand that this response to Syrian refugees is not new to Jordanians since Jordan hosts many refugees through history and treat them as brothers.

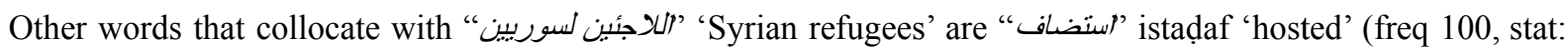
9.53287) and "استقبل' istaqbal 'welcomed/hosted' (freq: 40, Stat: 6.19645). The use of (ستضاف 'istadaf 'hosted' is significant since it indicates that Jordanian treats Syrians as guests. Jordanians are known for their hospitality to

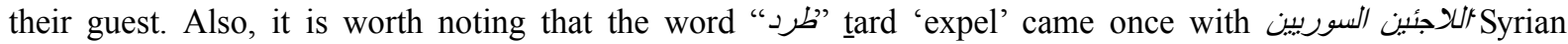
refugees' and it is not used within the Jordanian context.

A further examination of the word "ستضاف" istadaf 'hosted' indicates that this word collocates with " PaSba? 'burdens' (Freq: 20, Stat: 5.76091). Consider the concordance line below:

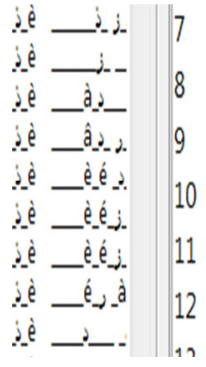

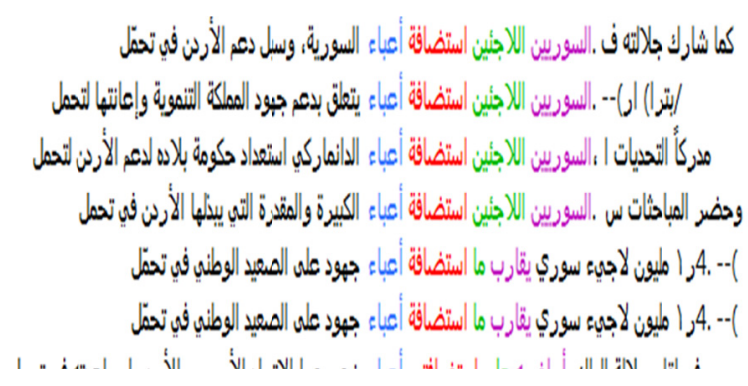

Figure 2. Collocates of /istadaf/

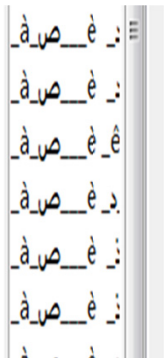


The use of "' "أعباء /RaSba?/ 'burdens' suggests that the Syrian refugees became a burden on Jordan after four years of the Syrian crisis. Jordanians see the Syrian refugees as quests and brothers. After four years of war in Syria, Jordanians believe that Syrians affected the sources and economy of Jordan negatively.

\subsubsection{Services and Resources}

This category includes the words that refer to the resources of Jordan and the services presented by the Jordanian government to the Syrian refugees. This category is further classified into subcategories, such as " "ضحنة//sihah/

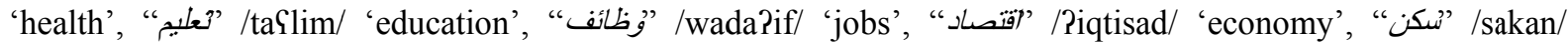
'housing', "مياه" /miyah/ 'water', etc. The study found out that the most frequent words were those which were used with the subcategories تعليام/taClim/ 'education' and صحة 'sihah/ 'health'.

\subsubsection{Education}

Before the Syrian refugee crisis, Jordan's educational system is considered a well-developed one. However, the arrival of the Syrian refugees lead to shortened class times, overcrowded classrooms, and double-shifting. The study found that in services and resources category, words related to education are the most frequent collocates

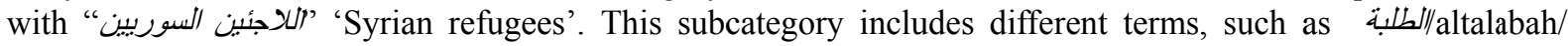
'students', الدعارس//almadaris/ 'schools' and تعليم/taClim/ 'education' as it is evident in the following table:

Table 2. Keywords related to education

\begin{tabular}{lll}
\hline Word & Freq. & Stat \\
\hline الطلبة 'students' & 98 & 9.75362 \\
المدارس 'schools' & 52 & 7.54362 \\
'education' & 31 & 6.73628 \\
\hline
\end{tabular}

A concordance line of the word " الطلبة"students' is presented below:

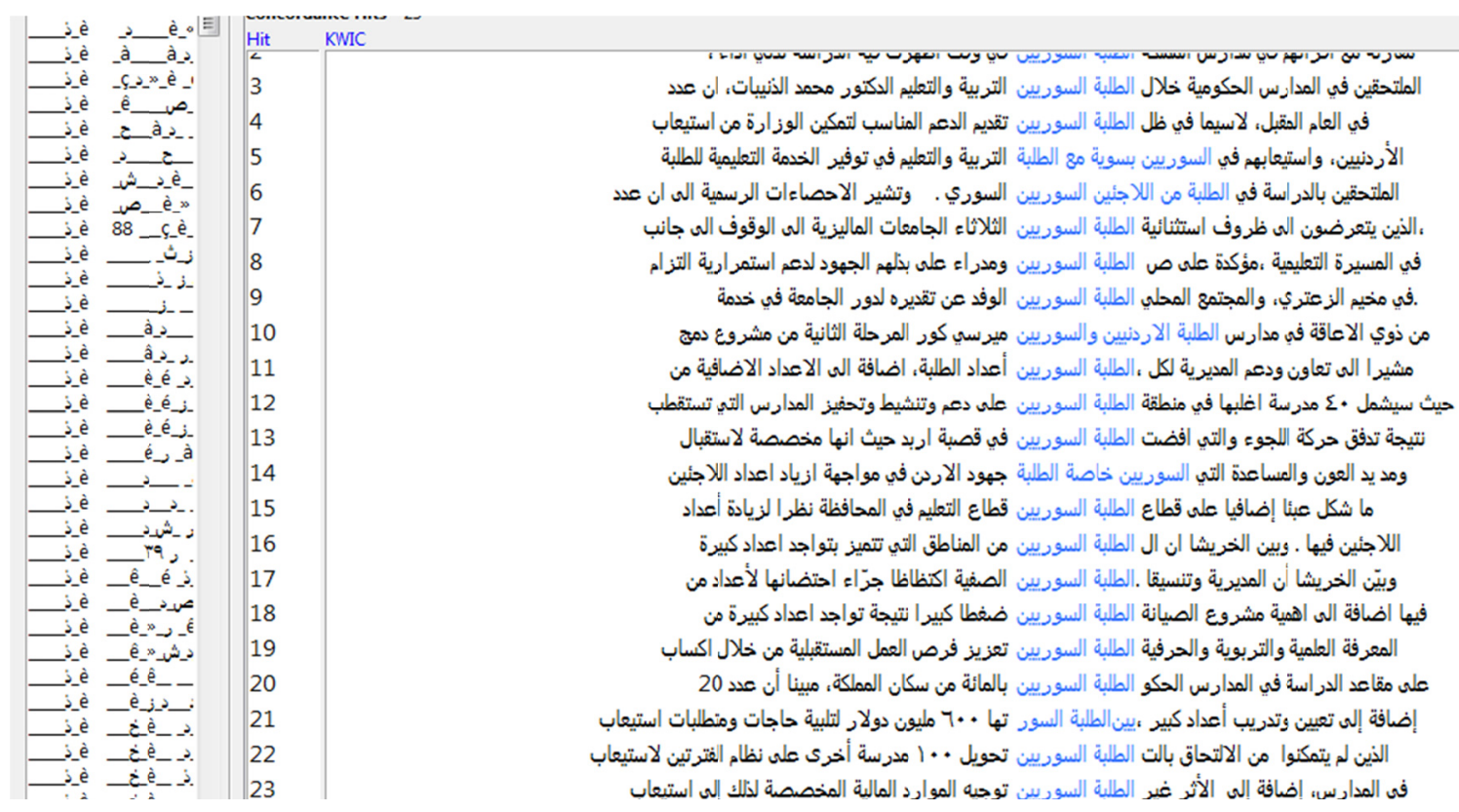

Figure 3. Concordance line of /talabah/ "students"

The analysis of concordance line shows that 80 percent of the usage of " الطلبة" 'students' comes with a context in which it talks about the negative effect of Syrian refugees on the Jordanian educational system. The increased number of Syrian students increases the pressure on classroom size, which forces the government to open double shifted schools. The government also expresses its inability to accept additional students, especially with limited international aid. Besides, Jordanians overstated their frustration concerning the pressure on the education sector. 


\subsubsection{Healthcare}

The study found that "'اللاجئين السوربين 'Syrian refugees' collates with words related to healthcare, such as صحين /sihiyah/ 'health' مستشفيات " mustaffayat 'hospitals', and علاجية /Coilad3yah/ 'medical' Consider the following concordance line:

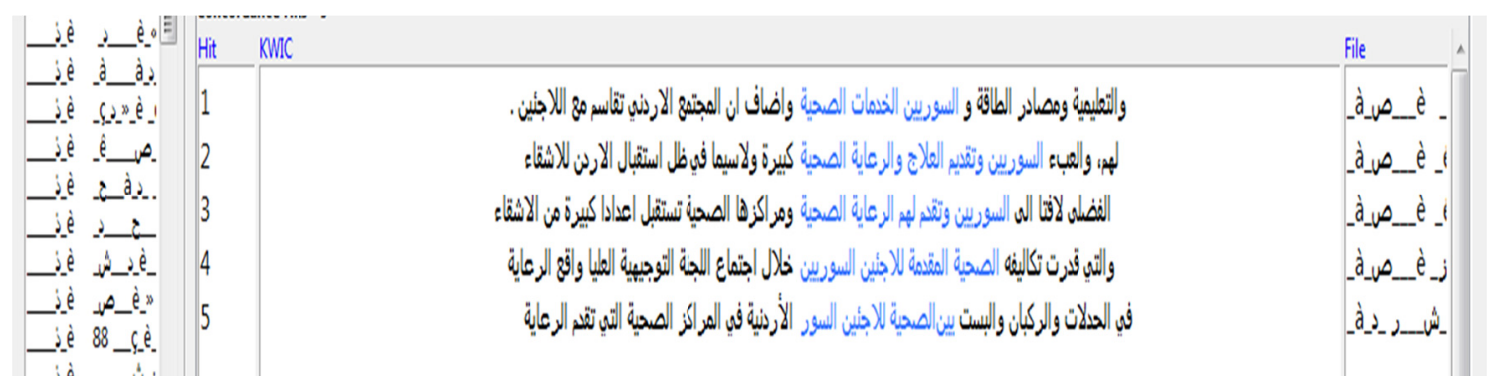

Figure 4. Concordance line for " "Syrian refugees"

As a result of the influx of Syrian refugees, the Jordanian medical system is under pressure, especially without international aid. Thus, Jordanians express their frustration because Syrian refugees made healthcare less accessible and more expensive for Jordanians.

\section{Conclusion}

The current study adopted a corpus-assisted critical discourse analysis to investigate the attitudes towards Syrian refugees in Jordan after five years of war in Syria. The corpus used in the study consisted of 1956589-word tokens compiled from Jordanian newspaper articles published between 2016 and 2018. The findings of the study revealed that Jordanians look at Syrians as "brothers" and "guests". However, Jordanian newspapers overstated the negative effect of Syrian refugees on the Jordanian economy, education, healthcare, etc. Jordanians frustrated because Syrians compete with them on their resources and governmental services. The study recommends conduction further research that investigates if there is a change in the attitudes of Jordanian newspapers towards Syrian refugees in 2020.

\section{References}

Aluthman, E. S. (2018). A Corpus-assisted Critical Discourse Analysis of the Discursive Representation of Immigration in the EU Referendum Debate. Arab World English Journal (AWEJ), 9(4), 19-38. https://doi.org/10.24093/awej/vol9no4.2

Baker, P. (2006). Using corpora in discourse analysis. London: Continuum.

Baker, P., Gabrielatos, C., \& Mcenery, T. (2013). Sketching Muslims: A Corpus Driven Analysis of Representations Around the Word 'Muslim' in the British Press 1998-2009. Applied Linguistics, 34(3), 255-278. https://doi.org/10.1093/applin/ams048

Ensslin, A., \& Johnson, S. (2006). Language in the news: investigating representations of 'Englishness' using WordSmith Tools. Corpora, 1(2), 153-185. https://doi.org/10.3366/cor.2006.1.2.153

Fairclough, N. (1995). Critical discourse analysis: The critical study of language. London, UK: Longman.

Fairclough, N. (2001). Language and power. Harlow, UK: Longman.

Hunston, S. (2002). Corpora in Applied Linguistics. Cambridge: Cambridge University Press. https://doi.org/10.1017/CBO9781139524773

Kandil, M. A. (2009). The Israeli-Palestinian conflict in American, Arab, and British media: Corpus-based critical discourse analysis. Unpublished doctoral dissertation. Georgia State University. USA.

Kim, K. (2014). Critical discourse analysis examining US news media discourses about North Korea: A corpus-based critical discourse analysis. Discourse and Society, 1(2), 1-22. https://doi.org/10.1177/0957926513516043

Partington, A. (2004). Corpora and discourse, a most congruous beast. In A. Partington, J. Morley \& L. Haarman (Eds.), Corpora and discourse (pp. 11-20). Bern, Switzerland: Peter Lang.

Partington, A. (2006). Metaphors, motifs and similes across discourse types: Corpus-assisted discourse studies 
(CADS) at work. In A. Stefanowitsch \& S. Gries (Eds.), Corpus-based approaches to metaphor and metonymy (pp. 267-304). Berlin, Germany: Mouton de Gruyter.

Salama, A. H. Y. (2011). Ideological collocation and the recontexualization of Wahhabi-Saudi Islam post-9/11: A synergy of corpus linguistics and critical discourse analysis. Discourse \& Society, 22(3), 315-342. https://doi.org/10.1177/0957926510395445

$\mathrm{Su}, \mathrm{H}$., \& Xiao, H. (2015). The discursive representation of Chinese dream: A corpus-based discourse analysis. International Journal of Linguistics and Communication, 3(1), 38-50. https://doi.org/10.15640/ijlc.v3n1a6

Tagnin, S., \& Teixeira, E. (2012). Translator-oriented, corpus-driven technical glossaries: the case of cooking terms. Corpora, 7(1), 51-67. https://doi.org/10.3366/cor.2012.0017

Ulum, O. (2016). Newspaper Ideology: A critical Discourse Analysis of Newspapers Ideology: A Critical Discourse Analysis of News Headlines on Syrian Refugees. Turkish Studies, 11(15), 541-552.

Van Dijk, T. A. (1996). Power and the news media. In D. Paletz \& C. Vinson (Eds.), Political communication and action (pp. 9-36). Cresskill, NJ: Hampton Press.

Van Dijk, T. A. (1997). Discourse as interaction in society. In T. A. Van Dijk (Ed.), Discourse as social interaction (vol. 2, pp. 1-37). Newbury Park, CA: Sage.

Van Dijk, T. A. (1998). Ideology: A multidisciplinary approach. London, UK: Sage.

Van Dijk, T. A. (2001). Critical discourse analysis. In D. Schiffrin, D. Tannen \& H. E. Hamilton (Eds.), The handbook of discourse analysis (pp. 352-371). Oxford, UK: Blackwell.

Wodak, R. (2001). What CDA is about-A summary of its history, important concepts and its developments. In R. Wodak \& M. Meyer (Eds.), Methods of critical discourse analysis. London, UK: Sage.

\section{Copyrights}

Copyright for this article is retained by the author, with first publication rights granted to the journal.

This is an open-access article distributed under the terms and conditions of the Creative Commons Attribution license (http://creativecommons.org/licenses/by/4.0/). 